our traditions and our history, and for the guidance and inspiration of our own and future generations. It subsists to a great degree upon gifts.

Our entire supervisory board serves without pay, its head serves for $\$ 3,000.00$ a year as curator, and without additional pay serves as a member and secretary of the Board of Conservation, establishing state parks.

The activities of the department cannot be added to any other nor can its functions be distributed at a saving of money, nor without great loss of efficiency.

\title{
A NOTABLE SPEECH OF BLACK HAWK
}

American annals contain many orations by, or attributed to, American Indians. Some of these efforts are among the most eloquent utterances of any time or tongue. Few readers of American history have not read and been moved by the words of Logan, the Mingo, and those of Keokuk, the Sac, and few will not accord these speeches the credit of having moved nations, both red and white, to or from war.

A speech of Black Hawk seldom to be found in Iowa historical sources is presented through the courtesy of Mr. A. N. Harbert in this number of the ANNals of Iowa, in the body of the reprinted copy of "Galland's Iowa Emigrant." Black Hawk was a Sac, not a chieftain, however, nor of special fame except for action in harmony with his own belief of tribal right. Yet, weighing his words by their results and by the response in our own natures as we gather their import, diminished by translation, the utterances of Black Hawk here presented must take place among the best of Indian efforts that have come down to us.

Whether Black Hawk ought to have uttered the language attributed to him, or to have remained silent, and whether he ought to have followed them up with war or have followed Keokuk's counsels for peace, is not our present question. But even white men cannot escape conclusion that from Indian racial standpoint Black Hawk was consistent in utterance and heroic in action, nor from the same viewpoint is there escape from conclusion that Keokuk was inconsistent in utterance and craven in action. From the white man's standpoint, of course, one condemns Black Hawk and commends Keokuk. But from every 
consideration Black Hawk in this speech rivals Keokuk in the fair object of all speech, namely, in producing results.

The moving planes of racial or tribal life have ever produced heat at their friction edges. The Indian life is ideally typified in the life and words of Black Hawk. The transition from savage toward civilized life is ideally typified in the life of Keokuk. The contrast and conflict in the two lives, if not in their respective utterances, present the ideal setting for drama in aboriginal life, for they reveal the elements of American frontier war.

Black Hawk, the loser, was defeated, deposed, driven "forty miles from the Mississippi," disgraced and denied all but a few friends at his death and burial at Iowaville. His grave was desecrated, his bones dragged forth for exhibition about the country as a curiosity, and only escaped that degradation by a timely accidental fire. Keokuk, blue-eyed, mixed blooded, exalted and bonused throughout the era of sale and dispossession from their ancient lands of his race, was vouchsafed the honors and ease of royalty until his death in Kansas.

Black Hawk's was the reward of loyalty to the ideals of a declining race; Keokuk's the reward of attachment to the ideals of a race ascendant. Black Hawk's speech, as set out by Doctor Galland, is among the greatest of the type which, in face of a lost cause, induces a population to throw its all upon the altar of its race.

\section{ABSTRACT OF THE MINUTES OF THE STATE BOARD OF CONSERVATION}

Septentren 19,1919

Reports by the Chairman.-That progress is being made on arrangements for the dedication of Backbone Park in Delaware County; that gentlemen from Emmettsburg desire a conference with the Executive Council and this Board concerning Medium Lake; that citizens have appointed committees to further the project of securing park land bordering on Twin Lakes, Calhoun County.

Area Visited.-The Board, in company with a committee of Fairfield gentlemen visited the proposed park near Fairfield known as the Chautauqua grounds and made note of its advantages and desirability.

OCTOBER 7, 1919

Inspecting Tours.-The secretary was directed to prepare specimen tours based on travel conveniences, to be ready for the 1920 season.

Dedication of Parks.- The dates of the dedication of the Keosauqua and Farmington parks were ordered left to the convenience of the people in those localities. 
Copyright of Annals of Iowa is the property of State of Iowa, by \& through the State Historical Society of Iowa and its content may not be copied or emailed to multiple sites or posted to a listserv without the copyright holder's express written permission. However, users may print, download, or email articles for individual use. 